\title{
The Third Road: Where Is It Leading Russia?
}

\author{
Alexander Benifand
}

The former Communists and the new Nationalists who, until recently, despised each other, seem to be merging and creating a united, NationalistCommunistbloc. Recentevents pointout that this new ideology is supported by well-developed political structures, a socio-economic foundation and even hit squads. Nationalist-Communists, who form an uncompromising and aggressive opposition to the government and the president, perceive themselves as a large and solid organization that has taken the so-called "third road." Their program for the reformation of Russia is approved by the Russian National Congress. This type of opposition became possible in a xenophobic and extremely frustrated society. According to Ilyushenko, "An inferiority complex

\section{Nationalist-Communists, who form an uncompro- mising and aggressive op- position to the government and the president, perceive themselves as a large and solid organization that has taken the so-called "third road."}

related to the collapse of the Empire, ethnic conflicts and mass impoverishment create a fertile soil for Nazi propaganda. Fascism poses itself as patriotism."1

Jews and populations in Caucasus and Central Asia top the list of the most hated people. The Moscow Public Opinion Research Centre found that 10 percent of the population are strongly against Jews, 11 percent believe that they have too much influence on politics in

Alexander Benifand is a Visiting Research Fellowat the Centre for Refugee Studies. the country, 9 percent believe in the Zionist conspiracy, and 10 percent do not want Jews to be their neighbours. ${ }^{2}$ What would be the government's reaction if these attitudes lead to action?

According to YuriLevada, a Russian sociologist, democratic governments have demonstrated their weakness in controlling these forces. ${ }^{3}$ Zhbankov, an employee of the Ministry of Justice, observes, "There is no law prohibiting the spread of fascist propaganda. If a fascist party comes to register we will do it." 4 Consequently, the number of

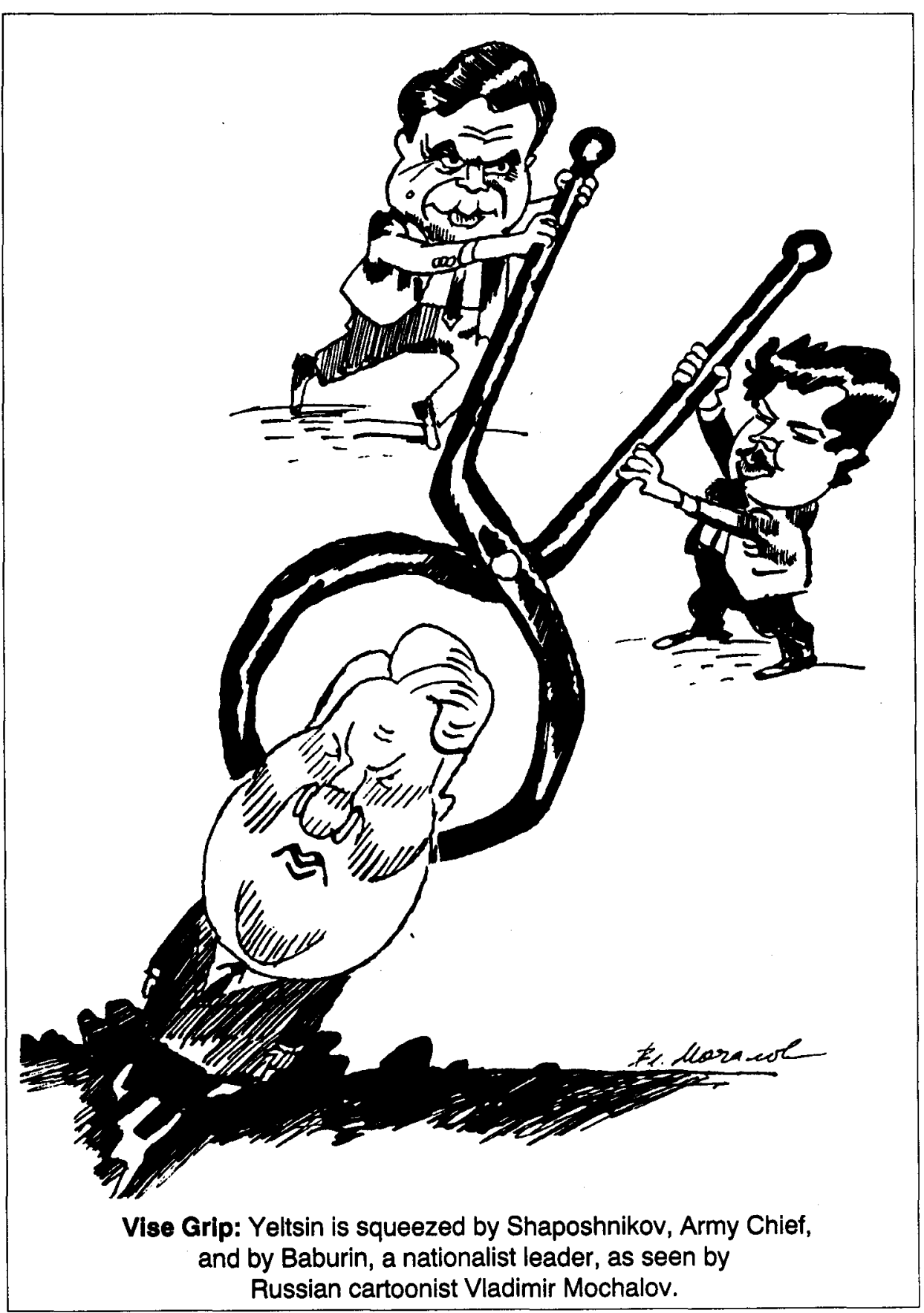

Refuge, Vol. 12, No. 4 (October 1992) 
chauvinist organizations is rapidly increasing and their activities are becoming more blatant and uninhibited. In an attempt to project an image of political democracy, the authorities leave their hostile actions unpunished.

Nationalist forces are consolidating and becoming well organized and coordinated. On June 12-13 there was a meeting of the Russian National Congress, a large-scale nationalist umbrella organization for all nationalist parties and groups that believe in sovereignty based on ethnic Russian principles. The Congress proclaimed the priority of Slavic over universal principles, and those of the Empire over those of the individual. They demanded the president's resignation. During the meeting of the Congress, Jews were often blamed for all evils. The Congress united 1,250 delegates from 117 cities and sixtynine organizations from all the republics of the former Soviet Union. 5

At the same time, factionalism is developing in the democratic camp. Some democrats are even joining the Nationalists allied with the Communists. On June 12, the first anniversary of Russian sovereignty, there was a meeting of Communist and fascist forces at the Ostankino television building. They demonstrated aggressively their opposition to the democratic forces. Tens of thousands of people demanded the president's resignation. Along with this demand, they also requested that Jews be purged from science, literature and arts and that they leave the country. The meeting was guarded by the Black Shirts from the Russian Youth Union. The meeting's objectives were to scandalize the government, to issue a warning, to frighten society and to test the grounds.

After the demonstration in Ostankino, some democratic members of the Russian Parliament requested that they discuss the fascist threat to democracy. This motion was voted down. At the same session, right-wing members stated that if the agreement made by Yeltsin with Bush in Washington is ratified, they will begin an armed struggle with this "antipopular" government that would make the demonstration in Ostankino look like child's play in comparison. ${ }^{6}$

There seems to be significant public support for demands made by the Nationalist-Communist bloc. A poll conducted by the Public Opinion Research Centre with 1,082 people in thirteen Russian cities points out that 14 percent of those interviewed said that the demonstratorsin Ostankino represented their interests. ${ }^{7}$ All these events raise fears among Russian Jews. Two weeks after the events in Ostankino, the number of Jews requesting visas to go to Israel went up by 10 percent and is continuing to increase. ${ }^{8}$

So far there has been no official reaction to the events in Ostankino, the growth of the number of public acts by neo-fascist organizations and the publication of anti-Semitic articles. This lack of official reaction encourages these activities. 圆

\section{Notes}

1. V. Ilyushenko, "Perezhivyot li Rossia krushenie imperii?" ("Will Russia Survive the Collapse of the Empire?"), Literaturnaya Gazeta 8 (February 19, 1992):11.

2. Yu Levada, "Vechno chuzhie" ("Forever Strangers"), Novoe Russkoe Slovo (August 1-2, 1992):7.

3. Ibid.

4. D. Zgersky, "Pechat' chernoi sotni" ("BlackHundred Press"), Novoe Vremya 3 (1992):34.

5. V. Nadein, "Zharkoe Leto v Ostankine" ("Hot Summer in Ostankino"), Moskouskie Novosti 25 (June 21, 1992):5; O. Bichkova, "Chernorubashichniki zovut na barrikadi" ("Black Shirts Are Calling to Join the Barricades"), op. cit., 7.

6. M. Khazanova, "Oni uzhe ne klouni" ("They Are Not Clowns Any More"), Novoe Russkoe Slovo (July 31, 1992):11.

7. "Expressopros" ("Express Opinion Poll"), Moskovskie Novosti 26 June 28, 1992):2.

8. A. Yefimova, "Zemlya obetovannaya: Vid s Bolshoi Ordinki" ("Promised Land: A View from Bolshoi Ordinki"), Novoe Russkoe Slovo (August 1, 1992):7.

\section{ANNUAL DINNER AND MEETINC FEDRUARY 4, 1093}

Yes, it's that time of year again! The Centre for Refugee Studies (CRS) cordially invites you and your friends to join us at our Annual Chinese Dinner and Meeting. The dinner is being held on February 4, 1993 at the Jade Garden Restaurant, 222 Spadina Avenue, Toronto.

\section{Vincent Kelly Award}

We are pleased to announce that we have invited the Honourable Kin Campbell, Minister of Justice and Attorney Ceneral of Canada to present the Vincent Kelly Award.

This year's award will be presented to Barbara Jackman andPlerre Buquette, twolawyers who have performed outstanding work on behalf of refugees. The dinner will focus on the legal profession and its contribution in the area of refugee studies.

\section{CRS Endowmont Fund}

Our Annual dinner is an opportunity for the Centre to bring together those interested and involved in refugee studies. This year the dinner will assist in funding two graduate legal students with their research through the CRS Endowment Fund:

Welook forward to you joining us or your financial support through a donation, which will then enable people from the refugee community to attend our dinner on your behalf.

Please copy the registration form on page 23 (of this issue) and send it to us at your earliest convenience. The CRS greatly appreciates your interest and support of our endeavours.

Join Us! 